\title{
Thermo-tectonic history of the Rio Grande Rise (South Atlantic Ocean)
}

PETER Christian HACKSPACHER ${ }^{1,2}$, BRUNO VENANCIO

DA SILVA ${ }^{1}$, UlRICH ANTON GLASMACHER ${ }^{3}$, GUSTAVO SOLDADO PERES ${ }^{1}$, ANDERSON COSTA DOS SANTOS ${ }^{2}$

${ }^{1}$ São Paulo State University (UNESP), Institute of Geosciences and Exact Sciences, Rio Claro, Brazil (peter.hackspacher@unesp.br, rochabt@gmail.com, gustavosoldadoperes@yahoo.com.br)

${ }^{2}$ Rio de Janeiro State University (UERJ), Geology Faculty, Rio de Janeiro, Brazil (andcostasantos@gmail.com)

${ }^{3}$ Heidelberg University, Institute of Earth Sciences, Heidelberg, Germany (ulrich.a.glasmacher@geow.uniheidelberg.de)

The Rio Grande Rise (RGR) consists of an aseismic, basaltic plateau currently submerged in the southwestern side of the South Atlantic Ocean. Its origin is under debate, ranging from a basaltic ridge formed by expressive intra-plate magmatism triggered by the arrival of the Tristan da Cunha plume in the Cretaceous to a microcontinent formed by fragmentation of the South American plate. The Cruzeiro do Sul Lineament (CSL), a major rift-like structure located in the western portion of the RGR (WRGR), is interpreted to be tectonically active from the Upper Cretaceous to the Middle Eocene. So far, understanding the development of the CSL is central to deciphering the thermo-tectonic history of the RGR with implications for the understanding of opening of the South Atlantic Ocean and the evolution of associated lithospheric plate margins. Thermal histories for these rocks (time-temperature paths) were obtained by the QTQt software. Single-grain AHe ages vary from $\sim 65$ to $5 \mathrm{Ma}$ and the thermal histories indicate an initial heating, probably related to plume evolution, followed by phase of cooling at the southern flank in the Eocene, and three phases of cooling at the northern flank: in the Eocene, Miocene, and Pliocene, respectively. Based on published seismic and stratigraphic data, the Eocene cooling is mainly interpreted in terms of magmatic cooling and basement uplift and erosion, whereas the Miocene and the Pliocene cooling probably reflect tectonic driven basement uplift and erosion. The preliminary AHe data suggest that the CSL was tectonically active at least until the Pliocene. Plume evolution also must be considered to explain these reactivations and uplifts. 